\title{
The Frailty of the Strong Executive
}

\author{
Peter D. Ore, Andrew P. Davis
}

"The same mind that creates the Corporation in society creates the bureaucracy in the state."

(Marx 1843)

\section{Introduction}

In 2018, more countries became "less democratic" than "more democratic" for the first time since 1979 (Lührmann and Wilson 2018). This autocratization has been driven, in part, by a long-term deterioration of traditional democratic constraints on executive power in judicial and legislative bodies (Pérez-Liñán, Schmidt, and Vairo 2019). Not coincidentally, this occurred alongside the construction of a transnational capitalist economic system, engineered by financiers and underwritten by central banks (Block 1996). As this project neared its feverish peak in the late 1990s, Peter Evans worried that, while states were unlikely to be totally "eclipsed" as they compete to retain and cultivate corporate citizens, "meaner, more repressive ways of organizing the state's role [in the global political economy] will be accepted as the only way of avoiding the collapse of public institutions" (1997: 64).

Evans held out hope that broadening the discourse on the possibilities of state action could lead to a more "embedded" social democratic future. But ultimately, he deemed the lean, mean state the more likely outcome. With business elites as their core constituency, Politicians would be rewarded for "restructuring the state's role to activities essential for sustaining the profitability of transnational markets" (ibid: 85). This means repurposing or demolishing the redistributive mechanisms of the mid-century administrative state -- Evans notes health and education access, among others -- in favor of "essential business services and security (domestic and global)" (86). In the United States, reality has come to approximate this alternative, as the ongoing deconstruction of social welfare, dramatic expansion of domestic and international surveillance infrastructure, militarization of police, and opening of public space to private extraction become ever more deeply woven into social life.

Evans did not comment on the concrete organization of such a state, but it seems clear that its changing role and constituency would bring concomitant changes in its shape, size, and structure. In our view, in an era of untrammeled capitalism, we should expect the organizational form of the state to come to resemble the everyday despotism of the firm. In this sense, our argument is a logical extension of Michael Burawoy's $(1979,1985)$ insights about the relationship between large scale shifts in political economies and the politics of the shop floor. Indeed, since Jimmy Carter's 1978 Civil Service Reform Act, the U.S. Federal government has been reorganized in its 
daily administrative structure to more effectively maintain the consent of its core constituents -- large corporations, investment banks, and the ultra-rich. Among other consequences of this process, which we describe in more detail below, is an increasing reliance on executive power, both as an independent branch of government and as an organizing principle. Tracing changes in the organization of the executive branch over this era, we read the Trump administration's unprecedented attacks on their own administrative capacity as a perverse consequence of a bipartisan, decades-long pursuit of an enterprise state.

From the perspective of enterprise state advocates, deliberative control over state bureaucracy is, at best, inefficient, and at worst, an unconscionable "politicization" of state functions. On the other hand, too much bureaucratic autonomy may reduce the state's sensitivity to the demands of private actors, themselves often executives of complex bureaucratic organizations ("job creators" requiring "government services"). The enterprise state, lean and mean, takes a third course between democracy and bureaucratic autonomy, one characterized by executive supremacy.

Ongoing neoliberal administrative reform has connected ever tighter circuits of information, decision-making power, and resources around ever smaller numbers of officials, ending finally with the Chief Executive of the United States. But this organizational form is inherently unstable. There are no real checks on Trump's authority to attack his own administration because a fundamental feature of executive power under neoliberalism is the privilege to check or contradict the (relatively autonomous) interests of the organization itself; indeed, this is the source of the executive's perceived efficiency.

After describing Trump's unprecedented attacks on the administrative state, we argue that he could not have been as successful or done so with impunity without a generation of neoliberal reforms in the executive branch. The enterprise state relies on executive control to protect policies favoring upwards redistribution from popular demands, discipline career bureaucrats, and, in general, help guarantee the state remains responsive to market hegemons. This "monocratic bureaucracy," we claim, is a deeply ingrained tendency of Liberal governance. Yet, in reaction to crises of overproduction, financial speculation, violent resistance, and ecological collapse over the last forty years, this tendency has hypertrophied into a core feature of the ruling superstructures of the United States political economy.

\section{The Hollowing Out of Federal Administration Under Trump}

The Trump administration is not normal. Among state bureaucrats, Marx writes, "the end of the state becomes [their] private end: a pursuit of higher posts, the building of a career." And, in the United States, this interest is often at odds with the particular policy agendas of presidents of either party. The first two presidential administrations of the 21 st century, in particular, were fully aware that the independent material interest in state administration that is essential to bureaucracy also frustrates executive control over it. But G.W. Bush and Obama, and the two presidents before them, were far less willing to renounce careerists than Trump. Their administrative strategy, unlike Trump's, conceived of these paper-pushers as the circuits through which executive decisions become concrete action. For reasons we can only speculate about here, Trump and his allies are abnormal in that they have chosen not to exercise that power. They have chosen, instead, to compromise it.

The Trump administration has carried out its hostile takeover with two main tactics: antagonistic appointments and attrition. Perhaps most damaging, administrative positions of 
public importance have been systematically and deliberately filled with individuals without the experience or training to take on the formal responsibilities of the position. Moreover, many of these nominations have centered on politicians, lawyers, and entertainers that have built careers as antagonists to the agencies they now lead. Texas Governor Rick Perry served as Secretary of Energy from 2017 to 2019 and oversaw the administration of U.S. nuclear power facilities, security, and billions of dollars in science and energy research, and was the first non-scientist to have this post on a permanent basis since 2005. Scott Pruitt, a serial litigant in suits against EPA as Oklahoma Attorney General, was initially chosen to lead the agency before being replaced by Andrew Wheeler, an oil and gas lobbyist. Eugene Scalia, son of the late Supreme Court Justice Antonin Scalia, infamous for defending Wal-Mart in labor disputes, is now the Secretary of Labor. While this recalls tactics embraced by the Bush administration, even the pretense of pursuing effective bureaucratic leadership is gone under Trump, as these administrators pursue policies that deliberately obfuscate and contradict the legislative purpose of their bureaus.

Second, the administration has had a remarkable amount of turnover in important positions. As Figure 1 illustrates, the Trump administration's turnover among senior-level officials by year 3 is atypically high (81\%) -- over 10\% higher than even the Reagan administration at the same point (70\%) (Dunn Tenpas 2019, Brookings 2020). In addition, this turnover is more meaningful than can be conveyed in a simple quantitative comparison of turnover among recent administrations at comparable points. Many important positions have seen serial turnover with officials being replaced three or more times, as described below in Figure 2.

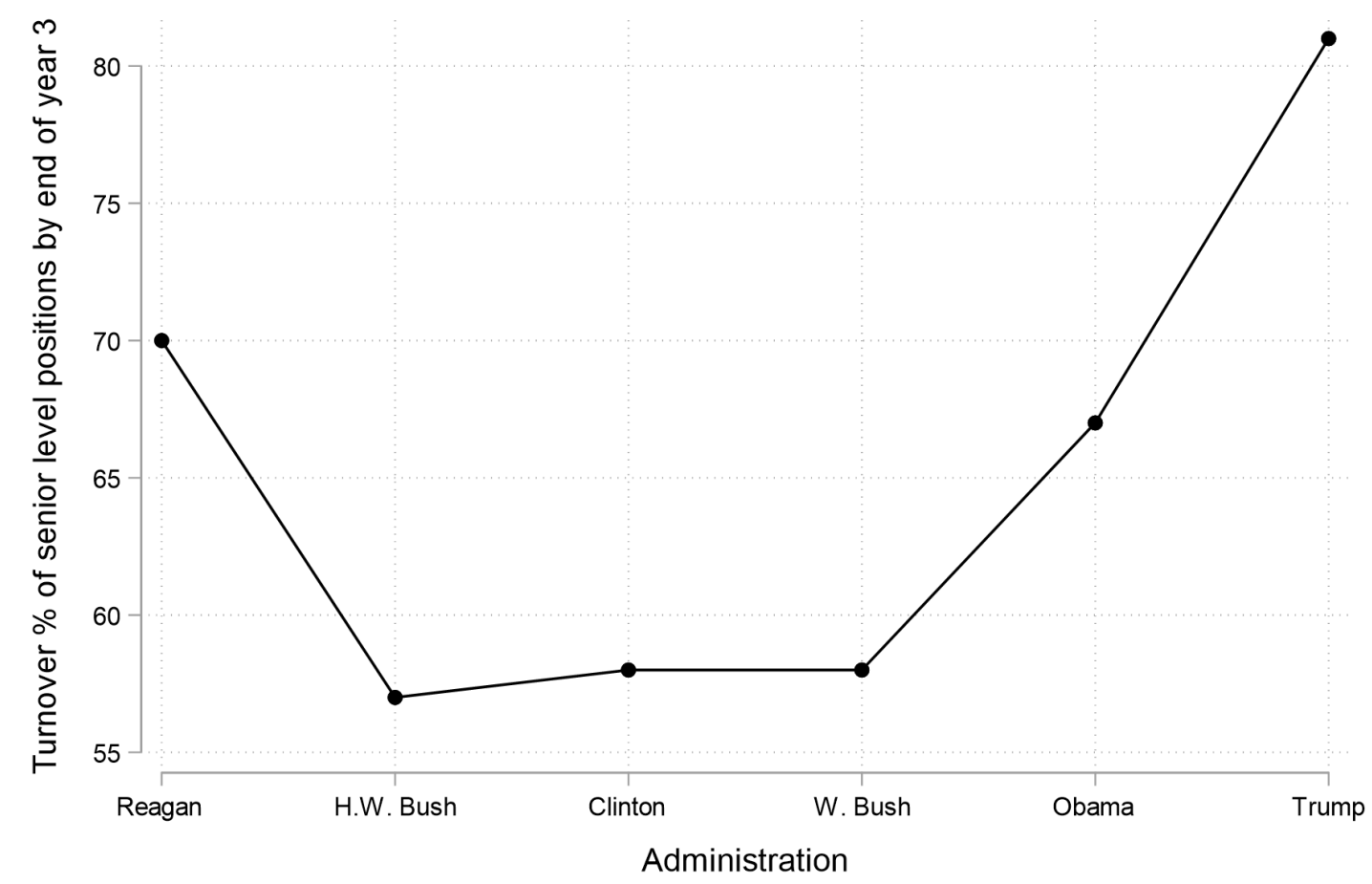

Figure 1. Plot of senior-level turnover in recent Presidential administrations

Source: Data are from Brookings report on "Tracking turnover in the Trump administration" https://www.brookings.edu/research/tracking-turnover-in-the-trump-administration/ 


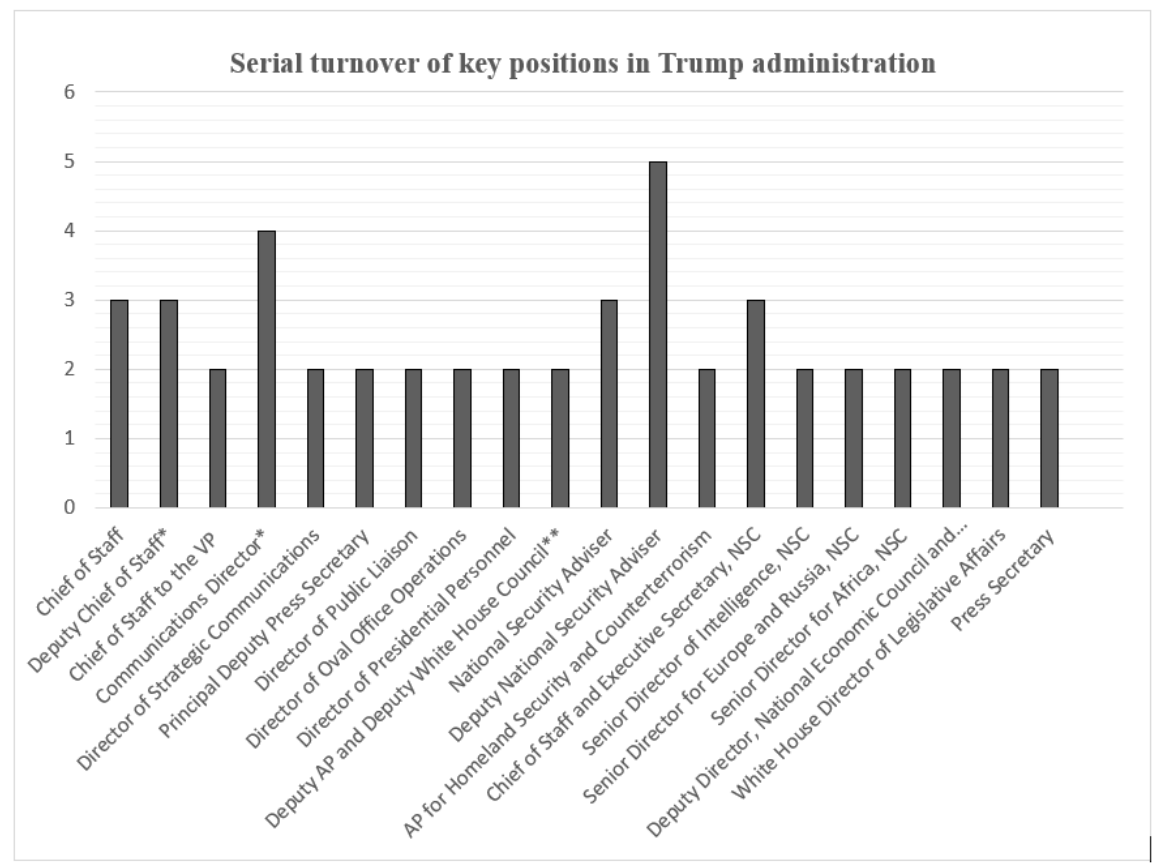

Figure 2. Serial turnover in the Trump administration (data source: Brookings)

Moreover, this attrition has not been matched by appointments of new personnel. For example, the administration has failed to staff important professional positions, notably in the U.S. Department of State. Needless to say, this level of turnover has significant impacts on the capacity of the state bureaucracy to function on a day-to-day basis, leading to significant administrative delays and well-publicized miscommunications.

Exacerbating the effects of antagonistic appointments and dramatic constriction of organizational capacity, the administration has replaced Senate-appointed posts with temporary "acting" positions that help the administration evade legislative oversight completely. Trump reportedly prefers acting positions to Senate-appointed posts as the former gives him the flexibility to quickly replace professional bureaucrats who might push back against his political agenda in favor of loyalists (USA Today 2019 https://www.usatoday.com/story/news/politics/ 2019/07/12/ trump-administration-run-numerous-acting-and-temporary-leaders/1703198001/). High profile positions such as the Chief of Staff, Defense Secretary, Secretary of Homeland Security, U.N. Ambassador, FEMA administrator, and Director of the Office of Personnel Management, among many others, have recently or continue to be led by officials in "acting" roles, rather than Senate-appointed posts.

Rather than co-opting or neutralizing career bureaucrats, the Trump administration maintains control by channeling authority to loyal advisors and family members and ruthlessly weeding out dissent and rewarding those with a long history of loyalty. Brooking Institute data on turnover in the Trump administration indicates that a disproportionate number of individuals who changed positions due to being "promoted" were individuals who worked for the pre-2016 Trump Organization or Trump presidential campaign (Brookings 2020). The appointment of individuals with family and personal ties to important positions has led some observers to characterize the Trump administration as a patrimonial system of authority (Riley 2017), in stark contrast to the 
Weberian "rationality" of enterprise governance. This has earned the Trump administration the loud criticism of leading theorists of the enterprise state.

Max Stier, president of the Partnership for Public Service, an important enterprise state advocacy group, has appeared in numerous news reports decrying the administration's tactics. In an interview for the New Yorker, Stier worried that the turnover and clientelism of the Trump administration represents a "resurgent spoils system. It is the breaking of an organization that was already under stress” (Osnos 2018). Brookings Institution fellow Kathryn Dunn Tenpas, who produced the widely used data analyses of Trump administration turnover (also cited above), wondered in an NPR interview why Trump-the-businessman doesn't understand the advantages of career bureaucrats, since, "In the private sector, corporations are all about how to retain their best people" (Naylor 2019). At the beginning of Trump's term, Stier warned that the executive branch is far more complex than the "family business" Trump is accustomed to running (Stier 2017). Trump's implicit response has been to transform the executive branch into a family business. Ironically, it is unlikely he could have gotten so far without decades of advocacy by Stier and his predecessors for a leaner, meaner, enterprise state.

Though much important analysis remains to be done, the Trump administration's motives are relatively clear. Deconstructing "the administrative state" has been a project of conservatives and business interests (including congressional Republicans) for a generation and more (e.g., Epstein 2008). And, despite supposedly robust American political institutions, legislative requirements, and clear threats to health and safety, there appear to be few, if any, bureaucratic or legal mechanisms to prevent his actions. With little mystery as to motive and means, then, we turn to an essential question: why is the contemporary American state so brittle? In short, our thesis is that, while Trump is not normal in his disinterest in co-opting the administrative capacity he inherited from his predecessors, his ability to contravene the letter and intent of the federal policy is intrinsic to the design of the enterprise state. The enterprise state, in turn, is an organizational form emerging as an element of elite reaction to the pressures described by Evans in 1997: heightened competition among states over transnational flows of people, money, and capital.

\section{Beyond the Antinomy of Public and Private Administration}

Liberal democracies are designed along the lines of Madison's phrase: "Ambition must be made to counteract ambition" (Madison, Federalist Paper 51). But stoking a multitude of potential political and social interests can make it difficult to get things done (Wolfe 1977). Indeed, ineffectiveness is seen as a major disadvantage of legislative bodies in the United States. For instance, despite the increasing levels of political polarization and ideological entrenchment, low levels of congressional approval are linked to Congressional gridlock (Newport 2018). Studies have found that public organizations in modern states have higher levels of formalization and standardization than private firms (Meyer 1979), although it is unclear whether formalization is related to the experience of red tape (Bozeman et al. 1992). More importantly, individuals perceive public institutions to be more inefficient and costly than private institutions.

Critics of bureaucratic theory have explored the irrationalities that arise from rational-legal bureaucracy. In the process of developing routine and impersonal decision-making structures, organizations dramatically increase the number of steps between decision and execution. "Red tape," or the regulatory checks that accompany processing decisions in institutions, can prevent the timely execution of tasks and engender a great deal of frustration (Merton 1940; Gouldner 
1952; Thompson 1961; Kaufman 1977; Scott and Pandey 2000). While the problem of whether red tape disproportionately affects public institutional performance compared to private firms remains an empirical question, it seems clear that the public associates a greater deal of red tape to public institutions (Bozeman and Loveless 1987; Bozeman et al. 1992). This perception has been the ideological grounding for bureaucratic reform initiatives that have become hallmarks of the enterprise state (Chomsky 1969).

Self-identified libertarian and conservative critics, in particular, point to public bureaucracy as the source of this popular discontent. The discontent is justified, they argue, because the Federal bureaucracy has accumulated unaccountable and obscure political powers. And yet, for these critics, private bureaucracies, culled by the cruel but judicious hands of the market, are naturally superior entities that should either replace or be models for public administration. Unsurprisingly, the preference for private bureaucracy is particularly strong in business management scholarship, where the "visible hand" of corporate administration is elevated to a historical force for public welfare and economic development (paradigmatically, see Chandler 1977), while public administration is characterized as an inefficient (or pernicious) means of harnessing the (generally assumed) human instinct for utility maximization, resulting in "rentierism" and other "inefficiencies."

As Marx writes in his notes for a Critique of Hegel's Philosophy of Right, the antinomy of these institutions is superficial. Public and private bureaucracies are better understood as codependent in form and function, forming a dialectical ellipse as each type of human organization continuously reshapes the other. Marx observed that German industry "struggle[d] against the existence of its premises" in its opposition to state bureaucracy in the early 19th century. If anything, this observation applies more directly to the history of the American corporation in the late 19 th and early 20 th centuries. The modern corporation began as a splinter of the state and soon grew into a form of privatized sovereignty (Roy 1997). The modern administrative state, in turn, rose alongside and became a constitutive element of the monopoly stage of capitalism (Baran and Sweezy 1966). As we show in the following section, by the end of the Carter administration, the transformation to a neoliberal global economy was accompanied by a complementary reorganization of the American state.

At mid-century, industrial giants and the bureaus of the American state had grown up into grudging partners in the construction of a renewed global capitalism. In the United States, this troubled relationship between public and private administration was fueled by seemingly indomitable economic growth. As public and private administrative apparatuses grew formidably large and comprehensive, popular consent was secured through the internal labor markets and moral economies made possible by intergenerational relationships between management and workers (Burawoy 1979).

The organizational ideology of the midcentury American state, triggered by a Great Depression and deeply conditioned by wartime economic policy, can be summarized, albeit crudely, in the concept of command and control management. Reflecting the fordist premises of the era, command and control maintains a careful division between those responsible for concept and execution (Braverman 1974), enforcing a quasi-militaristic logistical structure on the organization of the state. Indeed, this logic could be read into much of the legislation of this era, as in many instances, the Federal government literally commanded and controlled industry. Examples include the price controls of WWII, the now much-publicized Defense Production Act of 1950, and the National Environmental Policy Act of 1969. The basis of legitimacy for 
such administration was in the simulated pluralism of congressional lawmaking, which was, in fact, deeply stratified along the lines of race, class, and gender (Katznelson 2005).

As readers of Fast Capitalism are well aware, this arrangement would not hold. As the rest of the world emerged from the ruins of imperialism and industrialized warfare, the material and ideological bases of the postwar American political economy began to erode away. The racially segmented class compromise of the era began to fall apart as the Civil Rights movement won expanded access to the New Deal welfare state in the Great Society programs of the 1960s (Quadagno 1994). By the 1970s, the rise in the rate of profit was stagnating in a swamp of global overproduction (Brenner 2003), and the global south had entered the world stage demanding a more just global political economy (Slobodian 2018). In reaction, economic and political elites struggled to direct the global political economy such that its environmental, social, and economic costs would be absorbed by workers, consumers, and citizens, rather than those at the levers of power (Harvey 2005, Domhoff 1967). The consequences of this movement towards a leaner, meaner state would come to be associated with its dominant political and economic theory: neoliberalism.

It is, perhaps, a marker of its success that the prevailing association with neoliberalism is "small government" when, in fact, its rise to global hegemony has been accompanied by an unprecedented expansion in both international (e.g., the World Trade Organization, founded in 1995) and national government administrative power. As a recent wave of scholarship on the history and theory of neoliberalism shows (Cooper 2017, Briebricher 2018, Slobodian 2018), neoliberal theorists and the elites who cited them were not so much interested in dismantling the administrative state as in repurposing it. Rather than the size of the Federal government or its programs, for our purposes, the key distinction between the neoliberal state and the Keynesian models that preceded it is a structural shift away from the bureaucratic autonomy required by command and control policies. It is worth emphasizing that, rather than a hollow or weak state, these elites recognized that a strong state was (and remains) necessary to insulate markets and private wealth from these threats (Biebricher 2018, Slobodian 2018).

In general, advocates of neoliberalism have accomplished this reorientation of the state by subordinating public bureaucracy to private bureaucratic forms and organizations. Without necessarily diminishing it (and often by substantially expanding it), the neoliberal model of governance disciplines bureaucratic power to a market logic by increasing public use of private contractors, competitive mechanisms for resource allocation, and evaluating performance based on "metrics" such as cost-benefits analysis, or "customer satisfaction" measures (e.g., Fountain 2016), among numerous other well-documented organizational forms and procedures. In practice, this has meant the corrosion of legislative control over government bureaucracy, especially as it pertains to basic elements of capitalist political economy -- the maintenance of markets in land, labor, and money (Somers and Block 2014).

This hegemonic shift preoccupies much of contemporary critical scholarship. Its characteristics and consequences need not be enumerated in greater detail here. For the purposes of this essay, we instead focus on sketching its consequences for the organization of the executive branch. These consequences sum, in our view, to the enterprise state, an increasingly salient organizational form in contemporary governments, and one that is uniquely vulnerable to hostile takeovers. 


\section{Enterprise State and Executive Power}

Although the beginning of the neoliberal period is justifiably associated with Ronald Reagan, economic historians mark the famous "Volcker shocks," anti-inflationary measures taken by Federal Reserve Chairman Paul Volcker in the last year of Carter's administration, as the endpoint of the Keynesian postwar economy (Kotz 2017). These constituted major structural shifts in the American economy that would reshape social life for a generation and more. Less often remarked upon were nearly simultaneous shifts in the concrete organization of the American state. After successfully campaigning on civil service reform in the wake of the Watergate scandal, the Carter administration undertook the first recognizably neoliberal organizational reforms of the executive branch itself with the Civil Service Reform Act of 1978. As in previous eras, new state and economic organizations were born from the same womb, enemy brothers set to reshape the political and economic landscape of the United States.

The Civil Service Reform Act self-consciously re-formed Federal administration in the image of corporate organization, implementing performance appraisal, merit pay, an erosion of employee appeal rights, and the tripartite division of the old US Civil Service Commission into a human resources department (The Office of Personnel Management), a Merits Systems Protection Board (MSPB), and the Federal Labor Relations Authority (FLRA) (Dempsey 1979). Perhaps the most consequential reform was the Senior Executive Service (SES), which had the explicit intention of disembedding career executive administrators from their agencies by granting them special privileges and new vulnerabilities.

The SES put a cap on executive salaries, implemented performance rewards, and privileged political appointees with the authority to move career executives to different bureaus and positions (Rosen 1981). The SES also shifted top executives' (and only top executives) rank out of their position and into their person, making them nominally independent of their function within an agency and valued on the basis of their personal qualifications -- a distinct "service" of the most senior bureaucrats in the executive branch, newly accountable to their superiors (typically political appointees) rather than their subordinates.

The act was largely opposed by Federal personnel (Lynn and Vaden 1979) but found strong support among business interests, including the Business Roundtable and the U.S. Chamber of Commerce (Dempsey 1979). Former career administrators were particularly concerned that these reforms would undercut the independence of career bureaucrats since they made them newly vulnerable to the whim of political appointees (Rosen 1981). Others complained that these reforms naively took corporate models as the superior form of organization for government administration (Rosen 1978, Thayer 1978). Beyond their adoption of corporate "incentive structures" and institutional strategies for channeling and suppressing employee grievances (Edelman, Uggen, and Erlanger 1999), these reforms carried with them a new concept of leadership that has become a central characteristic of the enterprise state; a disembedded -- that is, systematically alienated from institutional context -- form of executive control that attempts to maximize both the independence of executives from the interests of their subordinates and their exposure to rewards and punishments for organizational performance.

These reforms and more like them would diffuse across time, space, and a global network of states (Lah and Perry 2008). Ten years after the Civil Service Reform Act was passed, the Brookings Institution and the American Enterprise Institute spearheaded a new reform initiative chaired by none other than Paul Volcker -- the National Commission on the Public Service (also 
known as the "Volcker Commission"). Appalled that "too many of the best of the nation's senior executives are ready to leave government, and not enough of its most talented young people are willing to join," the Commission sought to make government service newly attractive by suggesting improvements to "quality and performance at the senior administrative and professional levels of the Federal government" (National Commission on the Public Service 1989: 1-2). Among other things, the Commission recommended across-the-board pay increases, but only with an equivalent level of employment cuts in areas "no longer serving the public interest," the number of political appointees, and executive bonuses. Stringency in executive bonuses, in particular, was supposed to guarantee bonuses were used as performance incentives, rather than "hidden pay raises."

Very few of the Commission's recommendations were met with substantive responses, though it seems to have had an impact on public discourse (Cleary and Nelson 1993). Exceptions include a significant pay increase in the years following the Volcker Commission report (Aberbach 1991). Later reforms under the Clinton administration would take up the theme of reducing the size of the executive branch and making executive administrators more autonomous from their agencies.

Under the leadership of $\mathrm{Al}$ Gore, the Clinton administration generated a series of reports and initiatives which echoed many of the Volcker commission's recommendations. Above all, Gore's analyses advocated the use of "market dynamics” (Gore 1993), and various cost-cutting measures to produce a "Smaller, Better, Faster, Cheaper Government" (Gore 1995). Without going into too much detail, the main effects seem to have been a reduction in the Federal workforce and the further elaboration of the ideology and the organizational practices initiated by Carter's original reforms, especially the emphasis on disembedding executives from their bureaus. By the end of the Clinton administration, the number of executive branch employees had declined to fewer than 1800, far below the 2100-2200 range more characteristic of the 1970s and 1980s.

Throughout the 1990s, Federal spending had declined linearly with the number of executive branch personnel. This trend reversed course abruptly after 9/11, but the ratio of spending to raw organizational size had altered. Subsequent increases in Federal spending over the long war on terror and the 2008 financial crisis were paired with smaller increases in the number of executive branch employees, relative to previous years. By 2009, Federal spending had risen to unprecedented heights, but the number of employees had barely exceeded 1973 levels. Thus, the Bush and Obama years saw the layering of a mean state -- a massive surveillance and national police apparatus under the Homeland Security Office, paired with a historic bailout of financial interests -- over the lean state of the Clinton years. By the time Trump took office, the 21stcentury enterprise state had come into full flower.

The overall effect of these forty years of organizational transformation has been to make the executive branch more sensitive to external control, just as the overall power and authority of the executive branch has reached unparalleled heights. The Senior Executive Service (SES), now intrinsic to the organization of the Federal government, has made the executive branch highly sensitive to regime shifts. Not only has the number of political appointees increased, the SES incentivizes career bureaucrats to act more like political appointees. Senior executives, whose career prospects have been detached from the intra-bureau ranking system, are encouraged to act independently from the interests and technical requirements of their bureaus. Moreover, executive bonuses are given on metrics of success, which are deeply conditioned by the political priorities of the current administration. Finally, Carter's original legislation enabled appointees to neutralize inconvenient senior bureaucrats by shuffling them into ignominious positions. 
While some of the more important consequences may not have been intended (we doubt the elite politicians who crafted these reforms considered the possibility of a reality T.V. president), this form of organization was won through years of careful planning. Disembedding senior bureaucrats from their organizational context is an idea taken straight from the corporate world, where such measures are thought to increase executive flexibility and exposure to rewards and punishments for firm performance. Executives are supposed to be able to make intuitive decisions based on "signals," and their genius is supposedly validated (or not) by the blessings of the market. Corporate theorists view executive turnover as not necessarily a bad thing for firm performance, as new leadership is an important means of catalyzing creative destruction. The enterprise state is supposed to simulate this by exposing senior bureaucrats to the whims of political appointees and, ultimately, the President. It should be no surprise, then, when these reforms turn out to be the perfect set up for a hostile takeover.

In summary, the enterprise state is characterized by a concentration of political power in the executive branch and a reorganization of that branch along corporate lines. The reorganization involves a further centralization of power around the head of state, as bureaucratic leadership is disembedded from its organizational context and bound more closely to the head of state. In broad terms, this "monocratic" organizational structure has long been favored as "the most rational known means of exercising authority over human beings" (Weber 1978: 223). Indeed, for Weber, the only alternative to "monocratic bureaucracy" is "dilettantism" (ibid). Weber, the much-vaunted theorist of rational organization, thought only one entity could escape that iron cage -- the capitalist executive.

\footnotetext{
Superior to bureaucracy in the knowledge of techniques and facts is only the capitalist entrepreneur, within his own sphere of interest. He is the only type who has been able to maintain at least relative immunity from subjection to the control of rational bureaucratic knowledge. In large-scale organizations, all others are inevitably subject to bureaucratic control, just as they have fallen under the dominance of precision machinery in the mass production of goods. (Weber 1978: 225)
}

Weber's estimation of the executive as the only true subject under capitalism is a common refrain in liberal theory. While Locke's definition of property is usually read as an interaction between labor and the soil, it is, in fact, the direction of labor -- servants, women, and children -- that constitutes the original act of appropriation in his Second Treatise of Government. Hayek, in his essay "The Use of Knowledge in Society," famously argues against centralized planning on the theory that, since individual sellers have special knowledge of local circumstances, only they can interpret the meaning of price signals. These theorists tend to emphasize the equality of sellers in the marketplace. But, as Marx reminds us, any expansion of enterprise implies a proportional expansion in the despotism of production. This is certainly implicit in any regime of private property. Our contention is that it also applies to capitalist public administration in the neoliberal era. The designers of the enterprise state did not foresee the disastrous future they would help create, but Trump's abnormal turn toward despotism was nonetheless made possible only through their reforms.

\section{Conclusion}

Seeking to repurpose the regulatory state developed through legislative enactments in the postwar era, administrative reformers have turned increasingly to an "enterprise" bureaucracy led by 
disembedded executives. These reforms laid the groundwork for the abnormality of the Trump administration. Just as neoliberal policies caused widespread disenchantment with the American political establishment, executive administration has been significantly insulated from deliberative control. This has provided both the motive and the power for the Trump administration to undermine its own source of power in the executive branch. The Trump Administration's unprecedented dismantling of the administrative capacity of the executive, however unusual, is thus a predictable outcome of a generation's worth of neoliberal influence over the American state.

Capitalist democracies exist in an unstable system of contradictions and compensatory institutions. As one such compensatory institution, the enterprise state disembeds executive power as a way to address two fundamental contradictions of liberal democracy: how to maintain a regime of private despotism with a publicly funded state, and the state as both a necessary condition for markets and a threat to capitalist autonomy. As an extension of market logic to public administration, disembedded executives are more exposed to the preferences of the current administration and more capable of disrupting the organizations they oversee. This limits their capacity to implement or maintain legislative mandates, especially if they contradict the preferences of the President and their appointees, just as it enhances their ability to contradict the individual and collective interests of their subordinates. The neoliberal preference for a "monistic" state (Biebricher 2018) has been, to a significant degree, achieved through this identification of Federal administration with its Chief Executive Officers.

Trump, in his first term at least, represents an important development in economic and political liberalism, not a total break. But in Trump, we can see the outlines of a sinister new American liberalism, where the despotism of production is projected more fully onto the logic of government, and states are reconceived as enterprises bidding on a world market. These government enterprises would wield an unprecedented capacity for coercion, be ever more unified in the fickle will of a single personality, and be immunized to legislative intervention. As Peter Evans advised more than 20 years ago, we must get to work imagining alternative possibilities for state organization that improve the material conditions of survival while tipping the balance in favor of democracy.

\section{References}

Aberbach, Joel D. 1991. "Public Service and Administrative Reform in the United States: The Volcker Commission and the Bush Administration." International Review of Administrative Sciences 57: 403-419.

Baran, Paul and Paul M. Sweezy. 1966. Monopoly Capital. New York: Modern Reader.

Biebricher, Thomas. 2018. The Political Theory of Neoliberalism. Stanford: Stanford University Press.
Blau, Peter M. 1956. Bureaucracy in Modern Society. New York; Random House.

Block, Fred, and Margaret R. Somers. 2014. The Power of Market Fundamentalism. Harvard University Press.

Bozeman, Barry, Pamela N. Reed, and Patrick Scott. 1992. "Red Tape and Task Delays in Public and Private Organizations." Administration and Society 24 (3): 290-322. 
Brenner, R. 2003. The Boom and the Bubble: The U.S. in the World Economy. Verso.

Brookings. "Tracking Turnover in the Trump Administration." https://www.brookings.edu/research/ tracking-turnover-in-the-trump-administration/

Chandler, Alfred D. 1977. The Visible Hand: The Managerial Revolution in American Business. Harvard University Press.

Chomsky, Noam. 1969. American Power and the New Mandarins. The New Press.

Cleary, Robert E. and Kimberly Nelson. 1993. "The Volcker Commission Report Fades Away: A Case Study in Non-Implementation." Policy Studies Review 12 (3): 55-73.

Cooper, Melinda. 2017. Family Values: Between Neoliberalism and the New Social Conservatism. New York: Zone Books.

Constas, Helen. 1958. "Max Weber's Two Conceptions of Bureaucracy." American Journal of Sociology 63 (4): 400-409.

Dempsey, John R. "Carter Reorganization: A Midterm Appraisal." Public Administration Review 39(1): 74-78.

Domhoff, G. William. 1967. Who Rules America? Prentice Hall; 1 st ed.

Epstein, Richard A. 2008. "Why the modern administrative state is inconsistent with the rule of law." New York Journal of Law \& Liberty 3.

Evans, P. 1997. The Eclipse of the State? Reflections on Stateness in an Era of Globalization. World Politics 50(1): 62-87.

Fountain, Jane E. 2016. Building an Enterprise Government: Creating an Ecosystem for CrossAgency Collaboration in the Next Administration. Partnership for Public Service white paper.

Gore, Al. 1993. From Red Tape to Results: Creating a Government That Works Better and Costs Less, First Report of the National Performance Review. Washington.

Gore, Al. 1995. Common Sense Government: Works Better and Costs Less, Third Report of the National Performance Review. Washington.

Gouldner, A. 1952. "Red tape as a social problem." In Robert Merton, A. Gray, B. Hockey, \& H. Selvin (Eds.), Reader in bureaucracy. Glencoe, IL: The Free press.

Gramsci, Antonio. 1971. Selections from the prison notebooks. London: Lawrence and Wishart.
Hamilton, Alexander, or James Madison. Federalist No. 51: "The Structure of the Government Must Furnish the Proper Checks and Balances Between the Different Departments." New York Packet, February 8,1788 .

Harvey, David. 2005. A Brief History of Neoliberalism. Oxford: Oxford University Press.

Hayek, Friedrich. 1945. "The Use of Knowledge in Society." The American Economic Review 35(4): 519-530.

Hull, Matthew S. "Documents and bureaucracy." Annual review of anthropology 41 (2012): 251-267.

Locke, John. 2016. Second Treatise of Government and a Letter Concerning Toleration. Oxford: Oxford University Press.

Lynn, Naomi B. and Richard E. Vaden. 1979. "Bureaucratic Response to Civil Service Reform." Public Administration Review 39(4): 333-343.

Katznelson, Ira. 2005. When Affirmative Action Was White: An Untold History of Racial Inequality in Twentieth-Century America. WW Norton \& Company.

Kaufman, H. 1977. Red tape: Its origins, uses and abuses. Washington, DC: Brookings Institutions.

Kotz, David M. 2017. The Rise and Fall of Neoliberal Capitalism. Cambridge: Harvard University Press.

Madison, James. 1788. Federalist No. 51: "The Structure of the Government Must Furnish the Proper Checks and Balances Between the Different Departments." New York Packet, February 8, 1788.

Marx, Karl. [1843] 1970. Critique of Hegel's Philosophy of Right. Cambridge University Press.

Merton, Robert. 1940. "Bureaucratic structure and personality." Social Forces, 18: 560-568.

Meyer, Marshall W. 1979. Change in public bureaucracies. Cambridge University Press.

Mills, C. Wright. 1956. The Power Elite.

Lah, T.J. and James L. Perry. 2008. "The Diffusion of the Civil Service Reform Act of 1978 in OECD Countries: A Tale of Two Paths to Reform." Review of Public Personnel Administration 28(3): 282-299.

Naylor, Brian. 2019. "An Acting Government for the Trump Administration." National Public Radio. https://www.npr.org/2019/04/09/711094554/ an-acting-government-for-the-trump-administration

Newport, Frank. 2018. "What Americans Want Their Government to Do Now." Gallup Polling Matters. https:// news.gallup.com/opinion/polling-matters/244154/americans-government.aspx 
Osnos, Evan. 2018. "Trump VS. the 'Deep State"” The New Yorker. https://www.newyorker.com/ magazine/2018/05/21/trump-vs-the-deep-state

Pérez-Liñán, Anibal, Nicolás Schmidt \& Daniela Vairo (2019) Presidential hegemony and democratic backsliding in Latin America, 1925-2016, Democratization, 26:4, 606-625.

Quadagno, Jill S. 1994. The color of welfare: How racism undermined the war on poverty. Oxford University Press.

Report of the National Commission on the Public Service. 1989. Leadership for America: Rebuilding the Public Service. Washington.

Riley, Dylan John. 1997. “American Brumaire?” New Left Review. 103: 21-32.

Rosen, Bernard. 1978. "Merit and the President's Plan for Changing the Civil Service System" Public Administration Review 41(2): 203-207.

Rosen, Bernard. 1986. "Crises in the U.S. Civil Service." Public Administration Review 46(3): 207-214.

Scaff, Lawrence A. 2015. "Max Weber's Legacy." The Annual Review of Sociology, no. 28: 18-27.

Scott, James C. Seeing like a state: How certain schemes to improve the human condition have failed. Yale University Press, 1998.

Slobodian, Quinn. 2018. Globalists: The End of Empire and the Birth of Neoliberalism. Cambridge: Harvard University Press.

Stier, Max. 2017. “Trump's off to a rough start. Here's what can make his job easier." Washington Post. https://www.washingtonpost.com/opinions/trumpsoff-to-a-rough-start-heres-what-can-make-his-job-easier/2017/02/28/14906e64-fdca-11e6-8f41-ea6ed597e4ca_story.html

Swedberg, Richard. "The changing picture of Max Weber's sociology." Annual Review of Sociology 29, no. 1 (2003): 283-306.

Tenpas, Kathryn Dunn. 2019. Brookings. https:// www.brookings.edu/research/tracking-turnover-in-the-trump-administration/ accessed 12/31/2019.

Thayer, Frederick C. 1978. "The President's Management 'Reforms:' Theory X Triumphant." Public Administration Review 38(4): 309-314.

Tilly, Charles. 1985. "War Making and State Making as Organized Crime." In Eds. Peter Evans, Dietrich Rueschemeyer, and Theda Skocpol. Bringing the State Back In. Cambridge, Cambridge University Press.

Thompson, V. 1961. Modern Organization. New York: Alfred A. Knopf.
Weber, Max. 1978. Economy and Society: An Outline of Interpretive Sociology. Vol. 1. Berkeley: University of California Press.

Wolfe, Alan. 1977. The Limits of Legitimacy: Political Contradictions of Contemporary Capitalism. Free Press.

USA Todav. 2019. https://www.usatoday.com/story/ news/politics/2019/07/12/trump-administration-run-numerous-acting-and-temporary-leaders/1703198001/ 
